\title{
Boszorkányperek lejegyzési és kommunikációs stratégiái - Módszer, párhuzam, problémák ${ }^{*}$
}

1. Bevezetés. 16-18. századi boszorkányperes tanúvallomásokban (lásd 2. pont) vizsgálom a szövegalkotás jellemzőit, párhuzamba állítva az elhangzottak rögzítésének módját a napjainkra jellemző gyakorlattal. Ennek feltárásához a pillanatnyi beszédhelyzeten túl a történeti, társadalmi, kulturális és a jogi kontextus mellett az írás kontextusát (és az írnokokét $=$ scribal context), valamint a kommunikációs kontextust (diskurzusstratégiák) egyaránt figyelembe kell venni (HILTUNEN 2010: 65-67). A stratégia vagy diskurzusstratégia gyüjtőfogalomnak tekinthető (HILTUNEN 2010; DOTY 2007), a lejegyzö, a tanú vagy a vádlott szerepéhez kapcsolódó nyelvi viselkedésbeli lehetőségek, mintázatok, sémák összességét jelenti, amelyekből a helyzethez és a témához alkalmazkodva és a beszédpartnerrel egyezkedve válogatnak. A szóhasználatban - mivel bármely nyelvhasználó megnyilatkozásait stratégiák alakítják - alapvetően nem a választás tudatossága vagy tanultsága jelenik meg. A kommunikáció kontextusa több rétegből/aspektusból tevődik össze: értelemszerủen beletartozik a tanúk nyelvi viselkedése (mind az eljárásbeli szerepük szerint, mind a felidézett történetekben a közösség tagjaiként), illetőleg a boszorkánysággal vádolt személy nyelvi viselkedése (a tanúbeszámolók alapján, valamint - ha ismeretes - a kihallgatási szövegekből). E kontextus részének kell tekintenünk ugyanakkor a fogalmazó/lejegyző szerepét is: a közösségi elbeszélés-hagyomány és a bírósági szövegalkotás keverékéről beszélhetünk (HILTUNEN 2010: 70-71).

A lejegyzési stratégiák felvázolására azért is szükség van, mert a szövegtípus sajátja a változatosság, a lejegyzők maguk azonban ritkán azonosíthatók, ahogy a lehetséges közbeavatkozásaik egy része is. Még ha egyes forrásokban ismeretes is a lejegyző személye, akkor is problematikus, hogy az adott „kéz” mennyit alakított a tanú szövegén, mennyiben érinthetett tartalmilag is lényeges részleteket. Noha eredetileg cél lehetett a szó szerinti lejegyzés, a beszéd gyorsasága (az íráshoz képest) és a memória korlátai ezt értelemszerüen nem tették lehetővé. Míg más területeken lehet támaszkodni a korabeli kézikönyvekre, amelyek a jegyzőkönyv formai és tartalmi követelményeit összefoglalták (GRUND 2007a: 122-123), addig a magyar anyagban elsősorban a szövegekből következtethetünk a szövegalkotás stratégiáira. Az egyes beszámolók lejegyzése egyértelmủen nem egyetlen séma szerint zajlik: formulák nem terjednek ki a szövegalkotás minden aspektusára, a hivatalos szókincs pedig keveredik a mindennapi szóhasználattal. Ráadásul a fennmaradt szövegváltozatok nem kezdetleges jegyzetek, hanem általában tisztázatok, másolatok.

*A tanulmány az Emberi Erőforrások Minisztériuma ÚNKP-17-3 kódszámú Új Nemzeti Kiválóság Programjának támogatásával készült, az MTA Nyelvtudományi Intézetben zajló 116217 számú OTKA-projektum anyagait felhasználva. Ezúton köszönöm a lektori észrevételeket.

Magyar Nyelv 114. 2018: 185-200. DOI: 10.18349/MagyarNyelv.2018.2.185 
Jelenleg tehát csak közvetett módokon ragadhatók meg a rögzítés jellemzői, a szövegalkotás folyamataira is csak következtetni tudunk a szövegben található - magára az írás kontextusára is vonatkozó - jelzésekből. Rendelkezésre állnak ugyanakkor más források, ${ }^{1}$ amelyek - közvetett - párhuzamként kínálkoznak az itt vizsgált nyelvi anyag leírásához, értelmezéséhez. Ilyen a mai magyar nyelvü jegyzőkönyvezési gyakorlat a büntetőjogi esetekben (DOBOS 2010a, 2010b; SZABÓ 2010; VINNAI 2010a, 2010b). Fontos módszertani kérdés ugyanakkor az is, hogy a manapság megfigyelhető szövegalkotási sajátosságokat (és az azokhoz kapcsolódó következtetéseket) milyen korlátokkal alkalmazhatjuk a 16-18. századi magyar forrásokra, illetőleg hogy kialakulóban van-e már ezek hagyománya ekkoriban. Az alábbiakban szembesíteni fogom a napjaink jegyzőkönyvezésére vonatkozó elveket, mechanizmusokat a történeti szövegek gyakorlatával, válaszokat keresve arra is, hogy melyek azok a nyelvi jelenségek, amelyek a középmagyar korszak mindennapi nyelvhasználatára utalnak a szövegtípusban; egyáltalán „,adott”-nak tekinthetők-e ilyenek a szövegismeretből és/vagy a szinkróniából kiindulva.

E kezdeti stádiumban az adatgyüjtést tekintve bármiféle olyan megnyilvánulást figyelembe kell venni, amely a kérdésfeltevés alapján releváns lehet (nemcsak meghatározott elemeket). Egyaránt szó lesz korpuszalapú (Történeti magánéleti korpusz, DÖMÖTÖR et al. 2017), valamint a korpuszba egyelőre nem került kiadásokból (lásd lentebb) tallózó gyüjtések eredményéről is. Általánosabban megfogalmazva ahhoz a kérdéskörhöz kíván a dolgozat hozzájárulni, hogy árnyaltabb képet kapjunk a hivatali és a közösségi, természetes szövegalkotás interakciójáról, a szövegek mögötti (pragmatikai értelemben vett) egyezkedésről. Kérdés az is, hogy a tanúkihallgatást irányító kérdőpontokban jellegzetes „,körülményeknek megfelelően" megvallás megvalósul-e, vagy pusztán formula marad. Elöljáróban azt mondhatjuk, a tanúvallomásokban jellemzőbb a - legtágabb értelemben vett körülményeket is feldolgozó szövegalkotás, mint napjaink jegyzőkönyvezési gyakorlatában, noha igen változatos módon valósul meg. Ez a különbség elsősorban a történeti, jogi és társadalmi kontextussal magyarázható (lásd 3-5. pont).

2. Problémafelvetés. A forrás bemutatása. A tárgyalótermi diskurzusba tartozó múfajok - a vádlottak kihallgatási szövegeit és a vizsgálódási szakasz tanúvallomásait egyaránt ideértve - jogi érdekeltségük ellenére a beszélt nyelvhez is közel álló szövegtípusnak számítanak. A nemzetközi szakirodalom is beszélt nyelven alapulónak (speech-based) vagy beszélt nyelvhez kapcsolódónak (speechrelated, semi-vernacular) tartja; többek között: KYTÖ-WALKER 2003; GRUND et al. 2009: 65-66; HILTUNEN 2010; CULPEPER-KYTÖ 2010: 17-18, 57). A beszámolókban felidézett társalgások mellett a történetek ,itt és most"-ba idézése indokolja ezt a megállapítást. Valójában a bizonyítékgyüjtés idején elvégzett tanúkihallgatás nem a tárgyalóteremben zajlik, így annak szöveges eredménye inkább az eljárás részeként kapcsolódik az ezáltal tágabban értelmezett tárgyalótermi diskurzushoz (emellett a tanúk beszámolóira az eljárás későbbi szakaszában is hivatkoznak).

${ }^{1}$ Jelenleg nem sok párhuzamba állítható elemzés ismeretes, a salemi anyag kapcsán is 2007 körül kezdődött a lejegyzési/írnoki (pragmatikai) aspektus részletes kutatása („,but until now the scribal aspect has not been extensively studied", DOTY 2007: 25). 
A jogtörténeti munkákban kevéssé kerül előtérbe a tanúvallomások rögzítésének módja vagy a szöveg formálása (HAJDU 1985; újabban KONCZ 2007 - angol területen, nem kizárólagosan boszorkányperes tanúvallomások kapcsán hasonlóképpen, lásd GRUND 2011: 154-156). Annyi látszik bizonyosnak, hogy elvben a tanú szóbeli előadásából az ügyre tartozót és a lényegeset kellő részletességgel kell tartalmaznia a jegyzőkönyvnek (HAJDU 1985: 94-95; napjainkra is ez látszik érvényesnek, vö. DoBOs 2010a, 2010b; VINNAI 2010a, a részleteket lásd lentebb). Ez a séma azonban számos megvalósítási lehetőséggel bír - az erre vonatkozó jogszabályok érvényesítése pedig több tekintetben problematikus (VINNAI 2010a: 153, 171-173) -, tehát a kutatásban a nyelvészetnek kiemelt szerepe, feladata van (vö. SZABÓ 2010; a jog és nyelv típusú kutatások áttekintéséről lásd VINNAI 2010b).

Az egyszerüség kedvéért boszorkányperes tanúvallomás-nak nevezhető szövegtípus sajátja ugyanakkor a nemcsak tartalmi, hanem szerkezeti és stílusbeli változatosság is. A tanúbizonyítás az előzetes bizonyítási eljáráshoz tartozik, melyet a cselekmény felderítése során hajtottak végre (KÁLLAY 1985: 121). A tanúk kihallgatását a szolgabírók és esküdtek végzik, s általában közösség előtt zajlik, például közgyülésen. A kihallgatás kérdőpontok szerint történt: ha tudomása volt a hatóságnak az illető vádlott cselekedeteiről (feljelentések alapján), akkor határozottabban fogalmazták meg a kérdéseket - ami ugyanakkor nem jelentette azt, hogy kizárólag az ezekre vonatkozó információkat jegyezték le. Ellenkező esetben általános kérdéseket tettek fel a tanúnak, elsősorban a vádlott előéletére vonatkozóan (HAJDU 1985: 92-94; KoNCZ 2007: 197-198). Ennek megfelelően szabadon hagyták beszélni a tanúkat, az viszont lényeges volt, hogy egy-egy információ honnan származik, erre minden kihallgatáskor rákérdeztek, a tanúk pedig utaltak is rá. Egyaránt beszámolnak a velük történt eseményekről és a „közhírrel" hallott történetekröl.

Problematikus azonban annak a meghatározása, hogy valójában mit és menynyire részletesen rögzítettek az elhangzottakból a lejegyzők, érinthettek-e a változások, átfogalmazások tartalmilag is lényeges részleteket. Ezzel összefüggésben az is kérdés, hogy mennyiben voltak az egyes közbeavatkozások, módosítások tudatos törekvés eredményei, és mennyiben magyarázhatók a memória korlátaival, a felidézés töredékességével. Hasonlóan kérdéses, hogy az adott szövegek változataiból, tisztázatokból, másolatokból mi és milyen formában hozzáférhető (GRUND 2007a, 2007b; 2012; KYTÖ-WALKER 2003: 223-226; CULPEPER-KYTÖ 2010: 56-58). A lejegyzések korai szakaszai (jegyzetek, kulcsszók, esetleg gyorsírással készült változatok) ritkán ismeretesek. Kifejezetten a szövegváltozatok közötti módosítások kapcsán állapítja meg PETER GRUND azt, hogy salemi tanúvallomások javításaiból közel sem lehet teljes képet kapni a jegyzőkönyvezés folyamatáról (bár más körülmények között is zajlott, mint a magyar gyakorlatban) - a vádlottak kihallgatásai valamivel több eredménnyel kecsegtetnek. A tanúvallomások ugyanis túl rendezett képet mutatnak ahhoz, hogy közvetlen rögzítések legyenek, ráadásul vannak másolásra jellemző hibák, melyek korábban meglévő szövegváltozatokra, jegyzetekre, teljes-szöveg verziókra, de legalábbis igen kiterjedt jegyzetekre utalnak (GRUND 2007b: 19-21). A salemi perszövegek esetében sokszor tudható, ki az aktuális lejegyző, így bizonyos stratégiákat személyekhez is lehet kapcsolni - 
ugyanakkor mégsem azonosítható ilyen esetekben sem minden közbeavatkozás, illetőleg hogy mely nyelvi jellemzők kihez tartoznak (GRUND 2007a: 143-145, 2012: 44-45; GRUND et al. 2009: 67). A kérdés tehát gyakran akkor is nyitott marad, ha a lejegyzők személy szerint azonosíthatók (főként ha más forrás nem maradt fenn tőlük). Ezúttal a 16-18. századi tanúkihallgatásokat nem további beszélt nyelvi jellegünek számító szövegekkel hasonlítom össze, hanem a jegyzőkönyv szövegtípusán belül maradva, az idő dimenziója mentén keresek összefüggéseket.

3. Megközelítés. Az egyöntetűség (más terminológia szerint azonosság) elve szerint a jelenben megfigyelhető mechanizmusok (erők) és mintázatok segítségével magyarázhatók a történeti jelenségek, változások (LABOV 1965: 93; ROMAINE 1982: 122). Ez az elv bizonyos esetekben a mintázatok azonosításakor is müködtethetö. A tanúvallomások és más hivatali források beszélt nyelvi jellemzőit tekintve kommunikációs jelenségek alapján (káromkodás, hangadások, gesztusok, vö. PUSZTAI 1999), frazeológiai jellemzők szerint (B. GERGELY 2002); fonéma-graféma megfelelések, szórendi változatok, pragmatikai jellemzők nyomán (HAADER 2006: 48-51).

Nemcsak a grammatikai és pragmatikai vizsgálatok szempontjából lehet tekintetbe venni a mintázatok feltételezett azonosságának elvét, hanem a forráskiadás és a források felhasználása szempontjából is. A vélt azonosságra épülnek a kiejtést rekonstruáló szövegközlések; ezekben azonban fennáll annak a veszélye, hogy a mára valójában visszaszorult nyelvi elemet nem adekvát módon azonosítják. Például: ${ }^{2} 1755$ : „megfenyegette őtet, várjá, úgymond, tíz esztendő múlva is megkeserülöd az én elmenetemet” (MBF. 4: 583); ugyanez szándéka szerint betühü változatban: 1755: ,meg fenyegette őtett varra ugy mond tiz esztendő múlva is meg keserülöd az én el menetelemet" Bosz 2: 451. sz.). A modern, rekonstruált szövegváltozat átírása tehát morfémát és grammatikai kategóriát érinthet: a mondatszóvá vált rávár $>>v a ́ r+r a ́$ helyett egyszerüen igealakként értelmezték a kérdéses elemet (az elem grammatikalizációjáról és a további adatokról 1. VARGA 2017). Szintén nem helytálló a következő értelmezés: 1771: „No, Anuca megetetted Bölkényi Komának a fiát, meggyógyítsd, mert ha nem, megégetlek borsószalmában” (KISS szerk. 1998: 222). Egy másik közlésböl ugyanis kiderül, hogy nem a 'megmérgez' jelentésủ megétet, hanem a korszakra és a szövegtípusra oly jellemző megesz 'megbetegít, megront' - pl. 1735: ,az egy felemet megette Kovács Szabóné, és a másikát most eszi" (Bosz. 2: 412. sz.) - jelentésü igealak szerepel a kérdéses helyen: 1771: „Nó Amica megetted a Bölkényi koma fiát meggyógyítsd mert ha nem megigetlek borsószalmába" (MBKF. 314/852); a megesz jelentésváltozásáról 1. VARGA 2015). A történeti szókincs-, szöveg- és világismeret kialakítása ilyenkor sem nélkülözhető, ez jelzi az egyöntetűség alkalmazásának korlátait.

3.1. Lehetőségek. Noha az egyöntetüség elvének elsősorban a nyelvi változás magyarázatában vagy a mintázatok terjedésének meghatározásában van szerepe (LABOV 1965: 93; ROMAINE 1982: 122), a jelen vizsgálatban új, módszertani

${ }^{2}$ Az adatokat a kötetek alapján betühüen közlöm, a hivatkozás a TMK-ból elérhető szövegek esetében az év és a kötet rövidítése (Bosz. 1-3.), valamint a per száma alapján, ritkább esetben - a TMK.-ból egyelöre nem elérhető szövegek esetében - az oldalszám szerint történik. 
szempont az, hogy az egyöntetüség egyáltalán müködtethető-e a szövegalkotási stratégiák esetében, azaz a mai megoldások mennyire vetíthetők vissza a korábbi időszakokra, vagy - más nézőpontból - megvan-e ezeknek a hagyománya ekkoriban. A boszorkányperek a 18. század végéig lezárulnak (bár szórványosan a 19. század elejéről is kimutathatók), így a stratégiák történetisége, alakulásai természetesen nem vázolható fel a maga teljességében, hiszen a vizsgált források időbeli egymásra következése nem folytonos. A korszak úriszéki kihallgatásai pedig az ügyek jellegéből adódóan tekinthetők közvetett párhuzamnak. Ráadásul a (kivételesen) boszorkányságnak minősített vádak esetében az úriszéki eljárásban nagyobb jelentőségünek mutatkoznak az ún. tisztító eskük, mint a tanúbizonyítás (vö. Úriszék, Bevezetés 42-44; lásd a 95, 195, 231, 240, 372, 381. és 383. számú pereket).

A napjainkra jellemző jegyzőkönyvekben közismerten nem a tanú megformálásait követi a szövegalkotás, hanem a kihallgatást végző személy saját szavai és mondatszerkesztése szerint rögzülnek (DOBOS 2010a: 203; VINNAI 2010 a: 171). Fontos különbség mutatkozik természetesen a technológiai lehetőségekben, hiszen lehetőség van a jegyzőkönyv gyorsírással, kép- vagy hangfelvevővel vagy egyéb berendezéssel történő rögzítésére is, illetőleg a kihallgatások is közvetlenül megfigyelhetők (VINNAI 2010a: 168-169). Emellett manapság a jegyzőkönyvezés elveit rendeletek, jogszabályok határozzák meg, például azt, hogy mely tényeket kötelező jegyzőkönyvbe foglalni (VINNAI 2010a: 170-171). A vádlottak kikérdezése is feltételekhez kötött, a jogszabályi feltételek párhuzamba állíthatók a társalgás pragmatikai elveivel (DOBOS 2010b: 53-56).

Az átfogalmazás olyan mértékü is lehet, hogy a tanúk vagy a gyanúsítottak később nem is ismernek rá saját beszámolójukra (VINNAI 2010a: 169-170). A beszámolók ráadásul tartalmilag is átalakulnak, elsősorban az ügy szempontjából a jogi vonatkozású releváns részekre koncentrálva, azokat megőrizve. A jegyzőkönyvi rögzítés elveit tekintve a tárgyalótermi és tanúkihallgatási diskurzusok rögzítése a nyelven belüli fordítással állítható párhuzamba, melynek során olyan tendenciák figyelhetők meg, mint a nyelvhasználat idealizálása, a sztenderdizációs törekvések, eufemizmusnak tekinthető megoldások, a nonverbális kommunikáció kihagyása, valamint az explicitáció, azaz a „célnyelvi” igények szerinti kifejtés (SzABÓ 2010; DOBOS 2010a: 223-250; VINNAI 2010a: 175-180). A célnyelvi igény gyakran arra utal, hogy csak a jogi értelemben releváns részek kerülnek jegyzőkönyvbe.

A nyelvhasználat idealizálása az alábbiakban foglalható össze: 1 . a beszámoló kiegészítése olyan tartalmakkal, amelyek el sem hangzottak; 2. a szóbeli közlés homályosságát eloszlató módon részletezve a tartalmilag releváns egységeket; 3. ezzel együtt jár a töredékes és tőmondatokból bővített összetett mondatok létrehozása; 4. az idealizálás részéként „legalább egy regiszterrel feljebb emelkedik" a megformálás (SZABÓ 2010: 25-26; VINNAI 2010a: 178, 189). Ezzel együtt a bíróság tipikusan a tanúnak tulajdonítva kezeli a kész szöveget (a szóhasználatot és az információkat egyaránt VINNAI 2010a: 178-182). A továbbiakban ezeket a jellemzőket szembesítem a történeti anyaggal. A mai kihallgatások esetében megvan a lehetőség arra, hogy a jegyzőkönyvet és a tényleges vallomás hanganyagát - annak részleteit - pontról pontra összevessék (VINNAI 2010a: 180-181). Történetileg a legtöbb esetben a végleges szövegváltozatot ismerhetjük 
meg, azonban valamelyest az eredményböl is következtethetünk a folyamatra, a különféle stratégiákra.

3.2. ... és korlátok. A történeti anyaggal való összevetést megelőzően érdemes néhány szempontot, további tényezőt előzetesen jelezni. A mai jegyzőkönyvezés elvei szerint lehetőséget kell biztosítani, hogy a megkérdezett (tanú vagy gyanúsított) a vallomását összefüggően előadhassa, de erre a gyakorlatban nincs lehetőség, egyrészt a rögzítés tempója miatt, másrészt a kihallgatónak azokat az elemeket kell kiszürnie, amelyek a nyomozás szempontjából relevánsak (VINNAI 2010a: 172-173). Éppen ezért a vallomás összefüggő előadása alig fordul elő, akár azért is, mert többször is kikérdezhetik a vallomást, illetve másodjára csak bizonyos részleteket, de elsősorban az egyidejü rögzítés miatt; hazánkban a legtöbb kihallgatás szinte végig a kérdés-felelet-gépelés technikáját követve zajlik, ugyanakkor az eredmény összefüggő beszámolóként jelenik meg (VINNAI 2010a: 176-178).

A történeti szituációban eleve kérdés, hogy többé-kevésbé összefüggő vallomás hangozhatott-e el (utána kiegészített kérdésekkel és válaszokkal). A boszorkányperes jegyzőkönyvek általában összefüggő formájúak, ugyanakkor egyes lejegyzésekben nyilvánvaló, hogy a tartalmat tagoló és az olvasó figyelmét irányító kérdőpontok a későbbi tisztázás-másolás során, utólag kerültek bele a szövegbe 1731: ,Jollehet ugyan a szomszédságban lakott e Fatens Soos Eörsével, egyéb Boszorkányságát nem tapasztalta, hanem ad 2dum Mindenkoron szollották Boszorkánságárul, a kikkel haragot tartott” (Bosz. 2: 437. sz.); 1732: „, nem is hallotta, a kikkel valakinek vagy ártott, vagy használt vólna, hanem Ad 2 dum $\mathrm{Az}$ proxime mult 1731dik esztendöben ezen Vitnyédi kösségnek Tehén Csordája betegeskedvén" (Bosz. 2: 270. sz.). Ezek ismeretében az összefüggő történetmondásnak a lehetősége legalábbis nem zárható ki teljességgel ebben a forrásban. Mindenesetre a jegyzőkönyvbeli monológ formába felidézett párbeszédek, és időnként metakommunikatív kommentárok szövődnek (a kérdőpontokkal vagy további tanúkkal kapcsolatban).

A korszakban még nincs hivatalos (és ennek megfelelően sztenderdizált) nyelvváltozat, így legfeljebb intuitív törekvésekre találhatunk példát. Korábbi kutatások a nyelvjárási keveredés eseteit mutatták ki - az egyes kihallgatási szakaszok különböző jegyzői között, a normakövető és a helyi nyelvjárási alakok összjátékát eredményezve (részletesen lásd SZENTGYÖRGYI 2013), illetőleg a kétnyelvüség különféle fokozatait egyéni és közösségi viszonylatban (SZENTGYÖRGYI 2007). Az idealizálás kérdése tehát e tekintetben kevésbé lehetett tudatos.

A boszorkányperes anyag ismeretében nyilvánvaló, mégis említésre méltó különbség, hogy nincs mód a kérdező és a tanú/gyanúsított közötti egyezkedés feltárására olyan módon és mértékben, ahogy az napjainkra - hangfelvétel, a rendőr által diktafonba mondott szövegváltozat stb. segítségével - lehetségessé vált. Például napjainkban először több eldöntendő/választó vagy állítással határos kérdést tesznek fel: „Ismerem, nem ismerem? [...] Ismerem, haragszom rá vagy nem haragszom rá? [...] Tehát most jelenleg haragszik rá”. Más esetben megmutatkozik a stílussal kapcsolatos egyezkedés, bizonyos felidézett diskurzusrészletek kapcsán: „Persze, mondja nyugodtan, engem nem zavar”, míg a jegyzőkönyvben az idézet elmarad, egy utalásszerü, értékelő megjegyzés válik belőle (,iszonyúan 
átkozódott, szitkozódott" - VINNAI 2010a példái alapján). Az egyezkedés meglétére a 16-18. századi anyagban leginkább egyes szöveges megoldásokból, a kommunikációra vonatkozó megjegyzésekböl következtethetünk: 1748: amint szoktak beszillenyi az illyes Aszonyok (Bosz. 2: 295. sz.); 1700: egy mérges pattanás költ, melyet mondottanak Pokol Varknak (NB. 133); 1727: Tovább mivel födözték bé a pörléseket, nem akarván a fatens hallgatni, hanem dolgára menvén nem tudhatja (MBF. 2: 99); 1752: csak fül heggyel hallottam beszédét (MBF. 2: 236).

Az egyezkedés a történetmondás során felidézett párbeszédből is kimutatható, ezúttal inkább a közösségi szóhasználati jellemzőkre, ezen keresztül a közösség attitüdjére következtethetünk: 1744: Mi úgy szoktuk, úgymond, azt mondani, nem merjük mondani, hogy rontás (SzB. 372). Egyezkedésre utalnak azok a megjegyzések is, amelyek a későbbi olvasó számára tesznek világossá tartalmakat, információkat: 1754: Zainé mondotta volna valakinek a Tanú Ablakja alatt, hogy nem jó minden Aszonnyal jót tenni értvén a Tanút, mert bal itilettel vannak az ember felöl (Bosz. 1: 158. sz.); 1751: hogy az az madzagh (értvén a kordáját) vagyon az derekadon (Bosz. 2: 434. sz.); 1741: Francsics Vidáné, kit máskint Mátai Marinkának hinak (Bosz. 2: 277. sz.); 1731: nagy !ganyuja az Fátensnek sokszor nevezet Birta Mártonnéhoz; máskéntis az Falúban csak az vólt az neve, az az Boszorkány Bertáne (Bosz. 2: 315. sz.).

Napjaink formai szabálya és gyakorlata szerint a beszámolók első személyben fogalmazódnak meg, méghozzá annak érdekében, hogy a későbbi olvasó úgy érzékelje, mintha ő maga is élőszóban hallaná a vallomásokat (VINNAI 2010a: 170171). Ezzel szemben a boszorkányperes jegyzőkönyvekben az aktuális tanúk egyes szám első és harmadik személyben egyaránt szerepelhetnek, illetőleg időnként váltakozik is a kettő egymással. Olykor a vádlott kihallgatásában is megfigyelhető ez a kettősség. Az explicitté válást tehát ebből a szempontból is meg kell vizsgálni.

4. Összevető elemzés: szövegjellemzők, tendenciák. Az alábbiakban a főbb szinkrón szövegformálási stratégiákról lesz szó, elsősorban a „célnyelvi igények"-ről, a regiszter alakulásáról (eufemizmusok, stílusbeli változtatások, átfogalmazások), valamint annak kérdéséről, hogy a jogi kontextus ellenére a nonverbális kommunikáció és a környezeti vagy más módon látszólag az „ügyre” nem tartozó elemek beszüremkednek-e a kihallgatás jegyzőkönyvi változatába.

A nyelvi anyag bemutatását tekintve módszertanilag az a célravezetö, ha az elemzés során egyaránt tudunk idézni az adott kérdéskörrel kapcsolatos megállapítást alátámasztó és cáfoló szövegrészleteket is. Pragmatikai jelenségekröl lévén szó, kevésbé van mód arra, hogy az előfordulási valószínüségeket tekintetbe vegyük, mivel nem minden stratégiát tudunk szókincsalapon (korpuszos keresésre átfordítható módon) megragadni. Egyaránt szerepelnek részletek 16. és 18. századi tanúvallomásból, különböző megyékből - annak érdekében, hogy a kutatás ezen stádiumában dinamikus legyen az elemzés, vagyis ne mosódjanak el (esetleg jogi vagy néprajzi értelemben) első pillantásra kevésbé releváns különbségek.

4.1. Explicitáció, ,,célnyelvi igények”. Napjaink jegyzőkönyvezési gyakorlatát úgy kell végrehajtani a nyomozónak, „,hogy a lehető legpontosabban feltárjon egy múltbeli eseményt, de egyúttal a jövőbe is kell tekintenie, és úgy leírnia 
ezt az eseményt, hogy az jogilag is megállja a helyét az ügyészség és a bíróság elött" (VINNAI 2010a: 180). Ennek érdekében további részletekkel kiegészíti a beszámolót, melyek valójában el sem hangzottak a laikus szájából. A tanulmányban közölt szövegrészletekből és összevető táblázatból a következőben mutatkozik meg ez a stratégia: „Egy alkalommal löktem neki a falhoz” (= a gyanúsított bólint a feltett kérdésre, vö. VINNAI 2010a: 181). Az írott szövegben a rendör igyekszik eloszlatni a szóbeli közlés homályosságát, például (a gyanúsított ennyit mond: „mi be is me-ment ... Én nem foglalkoztam v-vele”; míg a jegyzőkönyvben ez olvasható: „Én nem foglalkoztam vele, talán meg sem vártam, amíg feláll a földről, hanem bementünk a lakásba”. Vagy: „Nem láttam végképp rajta.” A hivatalos szövegváltozat azonban ez: „Amikor vitatkozni kezdtünk, nem láttam Sz-nén sérülést". A kész szövegben a tö- és töredékes mondatokat bővített, összetett mondatokként olvashatjuk, pl. „Meglöktem. Semmi nem volt”. Míg a jegyzőkönyv szerint: „Nem ütöttem meg, tehát nem bántalmaztam, sem ököllel nem ütöttem, sem nem rugdostam" (vö. VINNAI 2010a: 181-182). Bár a mondathatár megállapítása történeti szövegekben problematikus, annyi kijelenthetö, hogy többszörös alá- és mellérendelések, közbeékelések, mondatátszövődések tarkítják a tanúvallomásokat, már a fogalmazványnak, piszkozatnak tartott szövegváltozatokban is.

A közölt szövegrészek alapján ugyanakkor elöfordul a tartalom tagoltabb megfogalmazása is, noha az elhangzott mondat sem tekinthető agrammatikusnak: „Nekiesett a falnak, o-olyan részeg volt”. A jegyzőkönyvben azonban ez látszik: „Ekkor ő nekiesett a falnak. Eléggé ittas is volt” (VINNAI 2010a: 181). Ennek a részletnek az a sajátossága, hogy a megnyilatkozó alapvetően direktebben fejezi ki az oksági összefüggést (olyan részeg volt a sértett, hogy nekiesett a falnak, implikálva, hogy nem a gyanúsított tehető ezért felelőssé), mint ahogy az a jegyzőkönyvben megjelenik. Az utóbbi esetben a külön mondatként konstruált részlet azzal, hogy csak hozzáfüzve kapcsolódik az előző gondolathoz, közvetetté teszi az elhangzott változatban még nyilvánvalóan kifejezett (vélt) oksági összefüggést.

A 16-18. századi tanúvallomások esetében természetesen az sem egyértelmü, hogy mi az, ami semmilyen formában nem hangozhatott el a kihallgatáskor - arra azonban találhatunk példát, amikor a természetes megfogalmazást legalább részlegesen felülírja a szituáció, illetőleg a hivatalos szituáció keltette elvárások. Ilyenek például az időbeli kivetítés, visszavetítés egyes megnyilvánulásai, amikor olyan jellemzővel utalnak az egyes szereplökre, amely a történet idején még nem volt érvényes: 1716: hanem az uczára csuszván mászván ki meg hólt Beke Mártonne, nagj fel szóval kiáltotta (Bosz. 1: 61. sz.); 1750: valamely napon néhaj Ura e fatens Aszonynak Biró Urtul haza jött (Bosz. 2: 428. sz.); 1721: a vason lévö Bán Györgyné bent teremvén (Bosz. 2: 259. sz.); 1741: az David Banyara az az raboskodó személyre (Bosz. 2: 418. sz.); 1716: az után tovább nem hagyta az Leányát meghólt Festő Jutkával beszéllenj (Bosz. 1: 61. sz.). Ezek a megjegyzések a szóbeli közlést pontosítják, a szereplők egyértelmü azonosítása érdekében történnek - ilyen tömörített formában manapság mégis visszásnak hatnának a jogi szövegben.

CECCONI szerint a korábbi korszak tanúvallomásai esetében alkalmazható az ALLAN BELL nevéhez köthető audience design 'hallgatóságra tervezés' terminus 
- nem stílusra, hanem a tartalomra vonatozóan (CECCONI 2010: 248). A boszorkányperes lejegyzésekre jellemző az időbeli és oksági összefüggések nyomatékos jelölése, illetőleg hogy megelőlegezi bizonyos tényezők, információk jelzését, azonosítását a későbbi olvasó számára, mint a korábban már idézett értvén másként (valamint vagyis, tudniillik) kezdetü pontosító részletek. Napjaink jegyzökönyveitől eltérően a boszorkányperes beszámolókban a vádlott és a tanú egyaránt szerepelhetnek egyes szám harmadik személyben is. Ez nemcsak a magyar forrásokra igaz, a korszakban az angol tanúvallomások következetesen további jelölésekkel, körülírással azonosítják a szereplöket (she this examinant, she the aforesaid Anne; KYTÖ-WALKER 2003: 223-224; azonban ez nem kizárólagos megoldás, van példa a kontextusra hagyatkozásra, vö. GRUND - WALKER 2011: 45). A magyar tanúvallomásokban sem példátlan a sokszor említett mint jelző, azonban egyáltalán nem kötelező vagy következetes módon jelenik meg.

Fontos azonban, hogy más perszövegekben nem egyszer nehézséget okoz az éppen aktuális cselekvő azonosítása, illetőleg a szituációs kontextus ismeretével válik egyértelművé, hogy épp kire/mire vonatkozik az adott cselekvés/történés: 1733: „látta, hogy Gál István Felesége képibe nagy Csörgéssel az ablakon bé ment egy Asszony, melyet látván az Fatens, elsivalkodott. Az Férje felkelvén, eltünt" (ti. az elsivalkodást kiváltó látomás; SUGÁR szerk. 1987: 141). A kontextus ismerete azért is szükséges lehet, mert a tanú és a vádlott egyaránt harmadik személyben szerepel: 1716: Tudgya nyilvan fatens hogy Pap Mihály Leanyara ment volt és erüszakot akart tenni Leanyan de hogy semmit nem vehetett rajta, az után Eördögh képpében rea járt, és kinzota eötet [tudniillik a vádlott, Lengyel István] (Bosz. 1: 29. sz.). Az oksági összefüggéseket sem mindig teszi explicitté a sorrend: 1755: az haja pedig le volt eresztve jól lattam es Annya szült mezitelen volt (mivel szép Hold vilag volt) (vö. a holdvilág inkább a látással összefüggésben releváns; Bosz. 3: 474. sz.). Az explicitáció összességében talán a legjellemzőbb tendencia, azonban további magyarázatra várnak azok az esetek, ahol a kontextusra hagyatkozás vagy más miatt megmarad az implicit, akár értelemzavaró fogalmazásmód.

4.2. A regiszter és az eufemizmusok. Ahhoz, hogy a tanúk és a gyanúsítottak „laikus” beszámolója a jogi eljárásban - az ügyészség, bíróság előtt - is megállja a helyét, a szóhasználatot is szükséges lehet megváltoztatni (VINNAI 2010a: 178-181). Részben stílusbeli módosításról, a regiszter emelkedéséről számolnak be, azonban ezek egy része rendeletben, jogszabályban rögzítve van (például gyilkolás helyett az emberölés a jogilag elfogadott terminus, vö. SZABÓ 2010: 26). Ezt a fajta változtatást a 16-18. századi anyagon aligha kérhetjük számon.

A korábbi diskurzusok, megszólalások felidézése szintén kevésbé jellemző napjaink jegyzőkönyveire, s bár az elhangzottaknak lehet jelentősége, azoknak is gyakran összefoglalásait látjuk, vagy éppen csak utalást, valamilyen értékelő elem (jelző, határozószó) mellett. Az alábbi esetben maga a megnyilatkozó is vonakodik a felidézett szóhasználattól - valószínủleg inkább a szituáció miatt, hogy vallomást kell tennie: „Én, én ne-nem, hát én nem hallottam, csa-csak any-annyit hogy izé átkozódott úgy hogy hát mondta hogy büdös kurva anyádat meg hát na olyan". A jegyzőkönyvből kimarad a helyzethez nem illő megnyilatkozás, inkább az ahhoz kapcsolódó elmarasztaló attitúd jelenik meg (valamint valóban emelke- 
dik a regiszter): „Én akkor sem, később sem hallottam, hogy fájlalta volna valamijét, csak iszonyúan átkozódott, szitkozódott" (vö. VINNAI 2010a: 180-181).

A boszorkányperes tanúvallomásokban nem ennyire egyértelmü az ilyen és ehhez hasonló megnyilvánulások kezelése. Különféle stratégiákról beszélhetünk: előfordul, hogy megtartják az oda nem illőnek vagy trágárnak tartott elemeket formulák nélkül, máskor a megtartott elem elött szabadkozó formula szerepel, megint más esetekben pedig eufemizmust használnak (általában szabadkozó formulával). A stratégiákat tekintve, ha egy kihallgatás több tanúvallomását vetjük össze, akkor sem derül ki, hogy egy-egy kevésbé szókimondó kifejezést, eufemizmust látva az aktuális tanú szóhasználatára kell-e következtetnünk, vagy a fogalmazó szóválasztására: 1754: azt javasolta: hogy böcsüllettel szólván, annak az emésztetivel kötnék a lábát, a kire gyanóság vagyon (Bosz. 1: 98. sz.) vö. 1749: hogy megh romlott Leányának (:Salvo honore:) a ganajját maga csizmájában a Leánynak keményben a füstre fel akasztotta (Bosz. 2: 328. sz.); 1742: az Tyukjainak S. V. alfelet sörtvéles fonállyal be varrtak (Bosz. 2: 282. sz.), vö. korábbi vallomásban: 1742: Tyukjainak S.V. az segeket sörtvéles fonállyal bé varták (Bosz. 2: 282. sz.). A kérdés tehát több tekintetben is nyitott. Annyi azonban bizonyos, hogy a regiszter közel sem annyira „emelkedik”, mint azt napjaink jegyzőkönyveiben látjuk. A korszakban nyilvánvalóan kevésbé volt szabályozva, mi megengedett, és mi nem a jogi eljárásra jellemző nyelvhasználatban. A korábban illetlen(nek tartott) részletek megjelölése önmagában nem magyarázható azzal, hogy ez volt a szokás, hiszen az érintett elemek bármelyike előfordulhatott mindenféle jelölés nélkül is. A szabadkozó formulák mellett is teret kaphatott a tanúk (vagy a történet más szereplöinek) természetes nyelvhasználata.

4.3. Diskurzusszervező/jelölő fordulatok, metakommunikatív jelzések, nonverbális kommunikáció. A napjainkra jellemző jegyzőkönyvezésből kötelezően kimarad a nonverbális kommunikáció, a beszélt nyelv homályossága, a hezitálás minden formája, akár a szövegalkotásra vonatkozó reflexiók is (DOBOS 2010a; VINNAI 2010a). Noha az hangzik el: „Hát, hát én hát, hát mit mondjak? E-ez egy pár pillanat volt, mikor ez megtörtént mi be is me-ment" mindössze annyi szerepel a jegyzőkönyvben: „Pár pillanat alatt történt” (VINNAI 2010a: 181-182). Természetesen ezúttal is problematikus a történeti anyaggal való szembesítés, hiszen nem tudhatjuk pontosan, mi is maradt ki a beszámolókból. Mégis arra lehet következtetni, hogy ebben a tekintetben távolodik el leginkább a boszorkányperes szövegalkotás a mostani jegyzőkönyvek nyelvhasználatától.

Noha a tanú/vádlott saját nonverbális jelzéseit nehezebb tetten érni a vallomás során (egy-egy kivételes helyzettől eltekintve: 1729: „Az fatens el vegezvén elöttünk fassioját akkor harmadszor ütötte ki az nyavalya" Bosz. 1: 151. sz.), a vallomás közben felidézett párbeszédek mellett mégis megtalálhatók bizonyos nonverbális gesztusok említései is a rögzített beszámolókban: 1741: „torka tátva kiáltotta a fatens, hogy haj föl Vidáné nyomorultya” (Bosz. 2: 277. sz.); 1743: „fejét haitogatván mondotta: Attkozott ki miát énnekem meg kölletik halnom" (Bosz. 2: 278. sz.); 1724: „hallotta tulajdon maga szájjábul Kós Andrásnénak: Maga mellyit erössen meg ütvin átkozott legyek” (Bosz. 1: 13. sz.); 1756: ,a füvet visgálván a fatens, látta hogy habókolva mégyen egy farkas a nyomás mezö felé" 
(Bosz. 3: 481. sz.); 1726: „az pitvar ajtaján bejött, és törte a kezét lamentálódván, hogy miért hoztak bút a fejére" (SzB. 54). Ez nyilván annak eredményeképpen történik, hogy a kérdőpontokban mindig felszólítják a tanút, hogy „voltaképpen” vagy ,cirkumstancialiter” vallja meg, mi is történt.

Bizonyos gesztusok különösen fontosakká válhatnak a történetben: 1753: harag szemmel tekinte az Legenre és haza ment, és mingyárt az Legenynek uja nagyon megh dagadot (Bosz. 1: 179. sz.); 1747: haragos szemet forditott reaja Hös Anna, akkor Eczaka mingjárt meg romlott a Gyermek (Bosz. 1: 198. sz.). Ilyenkor nem egyszerüen a nonverbális kommunikációról számolnak be a tanúk, hanem azt a vélekedésüket is kifejezik, hogy ez az ő szemükben a rontás, a boszorkányság része (vagy azzá vált a következmények ismeretében) - egy-egy gesztus utólag átértelmezve is jelentőséget kaphat. Szintén mindig rákérdeztek az információ forrására, s a tanúk erre is reflektáltak, föként ha számukra szokatlan, boszorkánygyanús dolgot éltek át: 1741: Ezeket pedig onnét tudgya a fatens referálni, mivel magával valoságossan, nem álom látásban történtek (Bosz. 2: 277. sz.); 1753: Nyilván és nem állomképpen történt Dolgokat Musa Ersebettül, és Kocza Katátul láttott (Bosz. 2: 348. sz.). Nem példátlan azonban az sem, hogy a tanúk kevésbé együttmüködők, s inkább elhárítják a válaszadást: 1745: Felesige mindazáltal a Fatensnek jobban observálta azért eskuttessék meg, ki foghja vallanyi mitt vett eszre hozzájok, férfiu levén nem sokat törödött vélek, nemis akart tudnyi felölök (Bosz. 2: 293. sz.); 1746: hanem eleget beszéltek felöllök kire nem sokat figyelmezet a fatens (Bosz. 2: 294. sz.); 1676: ki jövén az kis ajtón kivül, ott osztán mint volt, nem tudom (NB: 101).

Ha a fenti szinkrón szövegrészlethez hasonló hezitálásra nincs is példa a történeti anyagban, a tanúknak lehetőségük volt arra, hogy pontosítsák a beszámolójukat. Erre találunk példát a szövegekben (általában formulával jelezve a hozzátoldást): 1755: Hogy nem a Kiss Ferencz, hanem a Kiss György mondotta: Ördögh teremtette akar ki lesz, de eszt megh bannya. (Bosz. 2: 296. sz.); 1731: nem szájjábul hallotta Birtanénak, hanem Nagj Illesnétúl hogj szemere vetette Birtáné (Bosz. 2: 315. sz.); 1737: de azt nem mondhattya attul a Palyinkátul vagy mástul de azt tudgya hogy tebb Palyinka nem volt nála hanem tsak a kit meg itatott véle (Bosz. 2: 320. sz.). Megjelennek olyan megjegyzések is, amelyek a szövegalkotás folyamatára, a történések felidézésére vonatkoznak: 1722: az masik Aszszont ki lehetett nem vöttem eszemben (Bosz. 1: 34. sz.); 1734: , ,hogy ki fogták ithon is eőket világossan jut eszében, aztis tudgya, hogy a Pányva kötélrül a leánya vitte be eőket öszve füzvén mint a Lovakat szokták" (Bosz. 1: 84. sz.) 1747: „el lölte a hidegh, és mint edgy holnapigh lölte, s jut eszében a Tanunak, hogy az Anya ezen hidegh lölését Fiának a Rabra gyanétotta" (Bosz. 2: 422. sz.); 1747: nem nagy idővel az után, de hányad nap nem emlékezik a Fatens (Bosz. 2: 422. sz.); 1755: kinek a nevét akkor jól tutta de most nem jut eszében (Bosz. 2: 451. sz.); 1755: melly történt dologh után a mint jut eszében a Tanunak két vagy három nap mulva Edes Attya olly szöröncsétlen nyavalában esett (Bosz. 2: 296. sz.); 1756: „de miert cselekedte? nem jut feleségének beszédje esziben, hanem hogy esztet több falusiaktul is kivált magátul Tálos Györgytül hallotta közönségessen" (Bosz. 2: 404. sz.). 
A boszorkányperes tanúvallomásokban ráadásul teret kaphat a tanú gondolatmenete is - akár az elbeszélt történés részeként felidézve: 1677: az uton latta hogy Molnar Ferenczné füuet szedet volna, tsak gondolta magában, hogy nem kár volna megh égetny (Bosz. 1: 128. sz.); 1756: „,mégyen egy farkas a nyomás mező felé, gondolván a fatens hogy talám a juh kolompot hallotta meg, azért megyen arra" (Bosz. 2: 481. sz.). Ugyanakkor magukra az átélt történésekre, azok következményére is utalnak, ez is ,,az ügyre tartozik": 1750: de az időtül fogva is fölötte igen roszszúl vagyon, úgy hogy az mint a Fatenst kénozzák, ha azt mind elöl kellene beszélnyi, sok árkus papirosra sem érhatnák le (Bosz. 1: 95. sz.); 1750: de mivel gongya nem volt reá, kin történt nem emlékezik reá (Bosz. 2: 430. sz.).

A körülmények szerinti megvallás tehát fontos tényezője a boszorkányperes tanúbeszámolóknak, olyannyira, hogy a minél részletesebb felidézés, a tanú emlékezése és saját magáról és az ügyről kialakított vélekedése, hozzáállása is kimutatható a jegyzőkönyvekben. Ezeket manapság legalábbis átfogalmaznák, vagy még inkább kihagynák, a jogi értelemben releváns tények és az objektív megfogalmazás érdekében. A boszorkányperes ügyek természetét jól mutatja, hogy ezeknek a szubjektív viszonyulásoknak is jelentősége lehetett, legalábbis nem tartották annyira lényegtelennek, hogy minden esetben kihagyják őket a beszámoló írásos változatából.

5. Záró gondolatok, további problémák. Ahogy azt a napjainkra jellemző nyelvi anyaggal való összevetés is mutatja, a 16-18. századi boszorkányperek különleges forrást képviselnek a jegyzőkönyvezés szövegtípusában. Módszertani szempontból a következőket mondhatjuk. A manapság bevett jegyzőkönyvezési stratégiák korlátozottan vetíthetők vissza. A 16-18. századi jegyzőkönyv sok tekintetben redundánsnak tủnik mai szemmel (részben okkal, hiszen a későbbi eljárás is végig ezekre támaszkodik): többek között a szereplök azonosításának egyes eseteiben, az előtörténetekben, az események apróbb epizódokra bontásában, amelybe a felidézett diskurzusok belesimulnak. Emellett megvan benne az a lehetőség, hogy a korabeli nyelvhasználat bizonyos vonatkozásait hívebben őrizze meg. Beleértve azt is, ahogyan a tanú gondolatmenete, vélekedése, emlékezése belekerülhet a jegyzőkönyvbe. A ma inkább beszélt nyelvi, ezért ilyen kontextusban kerülendőnek tartott elemek - diskurzusjelölök stb. - megítélése is eltérö ezekben a szövegekben, hiszen a hivatalos kérdőpontokban sem kerülik az ilyesmit. A regiszter bizonyos tekintetben emelkedhet (a szóválasztással, ezért viszont nemcsak a lejegyző lehet a felelős), azonban korántsem olyan kiegyensúlyozottan, mint napjainkban. Vannak azonosítható törekvések, akár a szabadkozást, akár az explicit megfogalmazást tekintve, számos szöveg ismeretében azonban vegyes, kevésbé tudatos stratégiák mutathatók ki, nem lehet például eleve eldöntöttnek kezelni, hogy egy illetlennek számító szó kap-e ezzel kapcsolatos jelölést, sőt azt sem, hogy mi számít a korszakban ténylegesen illetlennek. A modern szövegalkotási tendenciák közül leginkább a későbbi olvasó tekintetbevétele igazolódik.

A stratégiák feltárása szempontjából fontos figyelembe venni, hogy a boszorkányperes tanúvallomás bizonyos értelemben „elszigetelt” forrás: nem a fennmaradt szövegek száma alapján, hiszen az különösen jelentős. A fö tényezö, 
amely elhatárolja ezeket a szövegeket a korszak többi forrásától, illetőleg a hasonló szövegtípusokkal való összevetést korlátozottá teszi - beleértve az úriszéki iratokat is -, az a kulturális beágyazottsága. Sok tekintetben meghatározza a szövegalkotást az a társadalmi-kulturális (és részben jogi) háttér, hogy bármilyen cselekvés, történés kellően gyanússá válhat ahhoz, hogy eljárást indítsanak - és le is folytassák azt - bárki ellen. Más ügyekben - amelyeket az úriszéki iratok tartalmaznak - egy-két tanú beszámolója elegendő, a boszorkányperekben számos megnyilatkozó előkerül egy-egy kihallgatáskor is (ami ráadásul ismételhető, vö. KONCZ 2007: 201-203). Ez a fajta esetlegesség vagy „korlátlanság” - mind a témakört, mind a résztvevők lehetséges számát tekintve - a tanúkihallgatás szövegében is megmutatkozik.

Az ügyre tartozó, jogilag releváns jelzők tehát igen tág értelmet nyernek (szemben a korszakban is viszonylag egyértelmü úriszéki ügyekkel). Nem magától értetődő, hogy a lejegyzés többlépcsős folyamatában végül minek lesz jelentősége, és mi nem kerül bele a későbbi jegyzőkönyvbe. Az idézett példák szerint ezen a téren is a sokféleség, a változatosság uralkodik, így az eredmények igen szélsőségesek lehetnek. A forrásokkal való folyamatos szembesítés nem hanyagolható el, mivel a szövegtípus egyedisége miatt minden megállapítást igazolást igényel. A modellalkotás, a formalizálás csak akkor elfogadható, ha az egyszerüsítés (szempontok, tényezők figyelmen kívül hagyása) nem fed el fontos különbségeket a szövegek között - akárcsak a boszorkányság vádja esetében, az azt feltáró szövegekben is bármilyen jellemző „gyanút” kell, hogy keltsen a kutatóban.

Kulcsszók: boszorkányperek, 16-18. század, tanúvallomás, egyöntetüség elve, írásbeli és kommunikációs kontextus.

\section{Források}

Bosz. = Magyarországi boszorkányperek 1529-1768 1-3. Közreadja: SCHRAM FERENC. Akadémiai Kiadó, Budapest, 1970/1983.

KISS ANDRÁS szerk. 1998. Boszorkányok, kuruzslók, szalmakoszorús paráznák. Kriterion Könyvkiadó, Bukarest-Kolozsvár.

KB. = Kolozsvári boszorkányperek 1564-1743. Szerk. PAKÓ LÁszLÓ - TÓTH G. PÉTER. Balassi Kiadó, Budapest, 2014.

MBF. = A magyarországi boszorkányság forrásai $1-4$. Szerk. BESSENYEI JózSEF etc. Balassi Kiadó, Budapest, 1997-2005.

MBKF. = Magyarországi boszorkányperek. Kisebb forráskiadványok gyüjteménye 1-2. Közreadja: KLANICZAY GÁBOR - KRISTÓF ILDIKÓ - PÓCS ÉVA. MTA, Budapest, 1989.

NB. = Nagybányai boszorkányperek. Szerk. BALOGH BÉLA. Balassi Kiadó, Budapest, 2003.

SUGÁR ISTVÁN szerk. 1987. = Bủbájosok, ördöngösök, boszorkányok Heves és Külső Szolnok vármegyékben. MTA, Budapest.

SzB. = Szegedi boszorkányperek 1726 - 1744. Szerk. BRANDL GergelY - TótH G. PÉTER. Balassi Kiadó, Budapest, 2016. 
TMK. = Történeti Magánéleti Korpusz. http://tmk.nytud.hu (2018. 06. 20.)

Úriszék = Úriszék. XVI-XVII. századi perszövegek. Szerk. VARGA ENDRE. Akadémiai Kiadó, Budapest, 1958.

\section{Hivatkozott irodalom}

Cecconi Elisabetta 2010. Witness Narratives in the 17th Century Trial Proceedings. A Case Study of Historical Courtroom Public Discourse. In: BROWNLEES, NiCOLAS et al. eds., The Language of Public and Private Communication in a Historical Perspective. Cambridge Scholars Publishing, Newcastle. 245-262.

CulPePER, JonATHAN - KYTÖ, MERJA 2000. Data in historical pragmatics. Spoken interaction (re)cast as writing. Journal of Historical Pragmatics 1: 175-199. https://doi.[-] org/10.1075/jhp.1.2.03cul

CulPePer, Jonathan - KYtÖ, MerJa 2010. Early Modern English Dialogues: Spoken Interaction as Writing. Cambridge University Press, Cambridge.

DoBos CsILla 2010a. Élőbeszéd és diskurzusrögzítés a tárgyalóteremben. In: SzABÓ szerk. 2010: 193-227.

DoBos CsILla 2010b. Jogi pragmatika. A tárgyalótermi kommunikáció pragmatikai szempontú vizsgálata. In: SZABÓ szerk. 2010: 29-63.

Doty, KATHLEEN 2007. Telling tales. The role of scribes in constructing the discourse of the Salem witchcraft trials. Journal of Historical Pragmatics 8/1: 25-41. https://[-] doi.org/10.1075/jhp.8.1.03dot

DÖMÖTÖR ADRIENNE - GUGÁN KATALIN - NOVÁK ATTILA - VARGA MÓNIKA 2017. Kiútkeresés a morfológiai labirintusból - korpuszépítés ó- és középmagyar kori magánéleti szövegekből. Nyelvtudományi Közlemények 113: 85-110. https://doi.[-] org/10.15776/NyK.2017.113.3

B. Gergely Piroska 2002. A közéleti és a beszélt nyelv viszonya az erdélyi fejedelemségben. In: HofFMANN ISTVÁN - JUHÁsz DEZSŐ - PÉNTEK JÁNOS szerk., Hungarológia és dimenzionális nyelvszemlélet. Elöadások az V. Nemzetközi Hungarológiai Kongresszuson. Debreceni Egyetem - Jyväskyläi Egyetem, DebrecenJyväskylä.187-199.

Grund, Peter J. 2007a. From Tongue to Text: The Transmission of the Salem Witchcraft Examination Records. American Speech 82/2: 119-150. https://doi.org/10.[-] 1215/00031283-2007-005

GRUND, PETER 2007b. The Anatomy of Correction: Additions, Cancelleations, and Changes in the Documents of the Salem Witchcraft Trials. Studia Neophilologica 79: 3-24. https://doi.org/10.1080/00393270701287439

GRUND, PETER 2011. Scribes and scribal practices. In: KYTÖ, MERJA - GRUND, PeTER WALKer, TERry Testifying to Language and Life in Early Modern England. John Benjamins Publishing Company, Amsterdam (Philadelphia). 147-181.

Grund, Peter J. 2012. Textual History as Language History? Text Categories, Corpora, Editions, and the Witness Depositions from the Salem Witch Trials. Studia Neophilologica 84: 40-54. https://doi.org/10.1080/00393274.2012.668071 
GRUnd, Peter et al. 2009. Linguistic introduction. In: Rosenthal, BERnARD gen. ed. Records of the Salem Witch-Hunt. Cambridge University Press, Cambridge. 64-89. https://doi.org/10.1017/9781107589766

Grund, Peter - WALKer, Terry 2011. Genre characteristics. In: KytÖ, MERJA - GrUND, PETER - WALKer, TERrY Testifying to Language and Life in Early Modern England. John Benjamins Publishing Company, Amsterdam (Philadelphia). 15-57. https://doi.org/10.1075/z.162

HAADER LEA 2006. Az írott és beszélt nyelv viszonyához egy újonnan felfedezett nyelvemlék kapcsán. In: BÜKY LÁsZLÓ - FORGÁCS TAMÁS szerk., A nyelvtörténeti kutatások újabb eredményei IV. JATEPress, Szeged. 47-53.

HAJDU LAJOS 1985. Büntett és büntetés Magyarországon a XVIII. század utolsó harmadában. Magvető Könyvkiadó, Budapest.

HiLTUNEN, Risto 2010. Discourse and context in a historical perspective. On courtroom interaction in Salem 1692. In: TANSKANEN, SHANA-KAISA et al. eds., Discourses in interaction. John Benjamins Publishing Company, Amsterdam (Philadelphia). 61-80.

KÁLlaY IstVÁN 1985. Úriszéki bíráskodás a XVIII-XIX. században. Akadémiai Kiadó, Budapest.

KonCZ IBOLYA KATALIN 2007. A boszorkányüldözés jogtörténeti kérdései a Német-Római Birodalomban és a Királyi Magyarországon. PhD értekezés, kézirat. Miskolci Egyetem, Miskolc. http://midra.uni-miskolc.hu/document/5649/1157.pdf (2018. 05. 30.)

KytÖ, MERJA - WALKer, TERry 2003. The Linguistic Study of Early Modern English Speech-Related Texts. How "Bad" Can "Bad" Data Be? Journal of English Linguistics 31/3: 221-248.

LABOV, WILLIAM 1965. On the mechanisms of linguistic change. In: KREIDLER, CHARLES W. ed., Report on the sixteenth annual round table meeting on linguistics and language studies. Georgetown University Press, Washington. 91-115.

PUSZTAi FERENC 1999. Beszélt nyelv a középmagyarban. Névtani Értesítő 21: 380-386.

Romaine, SuZANne 1982/2009. Socio-historical linguistics: its status and methodology. Cambridge University Press, Cambridge - New York. https://doi.org/10.1017/[-] cbo9780511720130

SzABÓ MiKLÓs 2010. Nyelvi átfordítások a jogban. In: SZABÓ szerk. 2010: 9-29.

SzABÓ MiKLÓS szerk. 2010. Nyelvében a jog - Nyelvhasználat a jogi eljárásban. Bíbor Kiadó, Miskolc.

SZENTGYÖRGYI RUDOLF 2007. A magyar-szlovák kétnyelvüség változatai egy XVII. századi boszorkányperben. In: HOFFMAN ISTVÁN - JUHÁsz DEZSŐ szerk., Nyelv, nemzet, identitás III. Nyelvi identitás és a nyelv dimenziói. Nemzetközi Magyarságtudományi Társaság, Debrecen-Budapest. 329-343.

SZENTGYÖRGYI RUDOLF 2013. Ablatívuszi határozóragjaink mikrorendszerének változásai a középmagyar kori boszorkányperekben. In: FORGÁcS TAMÁs - NÉMETH MIKLÓS - SinKOVICS BALÁZS szerk., A nyelvtörténeti kutatások újabb eredményei VII. SZTE, Szeged. 151-168.

VARGA MóNIKA 2015. „Te öttél meg engemet néne” - A megbetegedés metaforáiról boszorkányperekben. Magyar Nyelvör 139: 321-332. 
VARGA MÓNIKA 2017. A grammatikalizáció néhány esetéröl boszorkányperekben. In: GÉCSEG ZsUZSANNA szerk., Lingdok 16. Nyelvészdoktoranduszok dolgozatai. Szegedi Tudományegyetem Nyelvtudományi Doktori Iskola, Szeged. 101-120.

VINNAI EDINA 2010a. A diskurzus kötött rendje: Kihallgatás és jegyzőkönyvezés a magyar büntetőeljárásban. In: SzABÓ szerk. 2010: 153-191.

VINNAI EDINA 2010b. A ,jog és nyelv" kutatások. In: SZABÓ szerk. 2010: 65-90.

\section{On scribal and communicative strategies of witness depositions of witch trials}

The present paper explores the written and communicative context of witness depositions in 16-18th century Hungarian witch trials. In particular, it tries to account for the prossibilities and ways of scribes' interventions. As compared to present-day ways of recording statements in court, the historical material reveals a number of essential differences of principle: what can be most clearly detected is the pursuit of explicitation (in a particular amalgam with reliance on situational/thematic context); less clearly revealed are idealisation of language use and omission of peculiarities of oral discourse. All these are related to the particular legal and cultural embeddedness of witch trials.

Keywords: witch trials, 16-18th centuries, witness depositions, principle of uniformity, written and communicative context.

VARGA MÓNIKA

ELTE Eötvös Loránd Tudományegyetem

MTA Nyelvtudományi Intézet 